\title{
THE VANISHING WHOOPING CRANE
}

Some Questions and Tentative Answers

How many Whooping Cranes are alive today?

Probably fewer than one hundred. Fewer than forty are reported each winter from the coastal regions of Texas and Louisiana; fewer still are reported migrating through central Nebraska or summering in north-central Alberta, Saskatchewan, and Manitoba.

Was the Whooping Crane ever abundant?

About one hundred and twenty-five years ago it existed in impressive numbers in the interior of North America, from north-central Canada to Texas and Mexico. In 1811 one authority witnessed its migration along the Mississippi River and wrote: "The whole continent seemed as if giving up its quota of the species to swell the mighty host.... The clangor of these numerous legions passing along high in the air seemed almost deafening;... and as the vocal call continued nearly throughout the whole night without intermission, some idea may be formed of the immensity of the numbers now assembled on their annual joumey to the regions of the south." As late as 1865 it was reported in considerable numbers from southern Texas and extreme northeastern Mexico.

Where does the Whooping Crane breed?

The Whooping Crane formerly nested in the northern interior of North America from northwestern Illinois, northem Iowa, southern and western Minnesota, the Dakotas, and eastern and northern Montana north through nearly all of Manitoba, Saskatchewan, and easterm Alberta to west-central and southern Mackenzie. The last authentic record of its breeding in the United States was obtained in 1894 (Iowa); the last authentic record of $i \mathrm{tg}$ breeding in Canada was obtained in 1922 (Saskatchewan). It probably now nests only in north-central Saskatchewan, east-central Alberta, and west-central Manitoba.

Through which states does the Whooping Crane migrate?

Presumably it migrates from its nesting grounds through central North and South Dakota, Nebraska, Kansas, Oklahoma, and eastern Texas. This presumption is supported mainly by the regularity of its occurrence each spring and fall at the "Big Bend" of the River Platte in central Nebraska. It has not, however, been reported from Kansas and Oklahoma during the past thirty years.

Where does the Whooping Crane spend the winter?

Mainly in the coastal region of Texas. Fewer than thirty birds are seen each winter at the Arangas Wildlife Refuge near Austwell. A few have been reported from the King Ranch south of Corpus Christi. Within the last twenty-five years small numbers have been observed in the western coastal region of Louisiana. Although the bird is known to have wintered in northeastern Mexico almost a century ago, it has not been recorded there in recent years. As for alleged central Mexican records, they may be erroneous.

Where is a Whooping Crane nest gituated?

Generally in a big marsh. A typical nest is a heap of dead vegetation and débris about five feet in diameter, rising a foot or more from water a foot and a half deep. A depression in the top holds the eggs.

How many young are raised by a pair each year?

A Whooping Crane nest ordinarily holds two eggs. Three eggs are rare. Only one brood is raiged per breeding season. Three young is, therefore, the largest number one pair uan raise a year.

Can the Whooping Crane be easily recognized?

Yes. It is a large bird, over four feet tall, with a wing spread of approximately seven feet. The adult is pure white except for the black wing-tips, legs, and feet; yellow bill; and red featherless head (chiefly the crown and cheeks). The plumage 
of the immature bird is whitish, blotched (sometimes quite heavily) with must-color. The Whooping Crane flies with neck stretched straight forward as all cranes do, but it cannot be confused with the Sandhill Crane because that species has no white in its plumage. Seen under certain conditions, especially when high in the air or on the ground at great distance, the Whooping Crane may resemble certain other large white birds which occur within parts of its range. The accompanying chart serves to point out how these species differ in (1) length of legs, (2) position and shape of neck, (3) relative size of bill and head, and (4) wing pattern: The Great Blue Heron, often erroneously referred to as a crane, is predominantly slaty-blue in color. Its shape when standing and flying is similar to that of the American Egret (see chart).

Why is the Whooping Crane so called?

Because of its calls. The Whooping Crane has an extremely long trachea (wind-pipe) which is partly coiled up and encased in the breast bone and which, if stretched out, is nearly as long as the bird itself. The call notes arise within the lung-end of the trachea; as they pass through the long neck by way of the trachea, they are tremendously amplified by resonance. On windless days the powerful cries can be heard three miles off.

What has caused the Whooping Crane's decrease?

The bird shuns settled areas. The advance of civilization has pushed it gradually from the southern part of its breeding range and is probably continuing to push it northward now. Beyond a certain degree of latitude it cannot reproduce properly. Furthermore, the killing of migrating and wintering individuals has reduced the total population faster than it can replace itself. The Whooping Crane, unlike many species of birds, cannot withstand the drain on its population resulting from deaths from natural causes coupled with killing by man. Its reproductive capacity (maximum only three young per pair per season) is not great enough.

\section{Is the Whooping Crane protected by law?}

It is rigidly protected by both the United States and Canada and by all states and provinces thereof.

\section{Can the Whooping Crane be saved from extinction?}

Yes. If the remaining stock continues to be vigorous and maintains a well-balanced sex-ratio, the Whooping Crane population can be restored. Two other large American birds, the California Condor and Trumpeter Swan, whose numbers were seriously reduced, are now on the increase, thereby offering encouragement. All Whooping Cranes now extant appear to be in good health.

What is being done to save the Whooping Crane?

The National Audubon Society and the United States Fish and Wildlife Service are jointily sponsoring intensive field investigations of the bird in its whole range from north-central Canada to northern Mexico. These investigations will emphasize the relation of the bird's welfare to all factors in the environment including climate, water-level, plant and animal life, and man. The project is designed primarily to find ways and means of restoring the Whooping Crane as a common bird throughout much of its former range.

What can you do to help save the Whooping Crane?

There are two things which you can do: (1) Report at once any observations that you have made on Whooping Cranes at any time in your life. Especially desirable are (a) exact dates and localities, (b) numbers seen, and (c) observations on activities. Recent observations are particularly important. (2) Encourage every person you know who lives in a region, known or thought to be inhabited by whooping Cranes at any time of the year, to watch for the birds and report their occurrence to you at once. The smallest item of information may provide an important clue, so send it along. Send all records and observations to Fred G. Bard, Curator, Provincial Museum, Regina, Saskatchewan. Mr. Bard is conducting the present joint investigation in Canada. 


\section{WHOOPING CRANE}

\section{Threatened with Extinction}

\section{HAVE YOU SEEN ANY?}

WHERE?

WHEN?

The National Audubon Society and the U. S. Fish and Wildlife Service are attempting to save this magnificent bird. If you have seen any, send (1) the NUMBERS of individuals seen, (2) the EXACT LOCALITIES where seen, and (3) the DATES when seen to Fred G. Bard, Curator, Provincial Museum, Regina, Saskatchewan. Your cooperation is greatly desired.
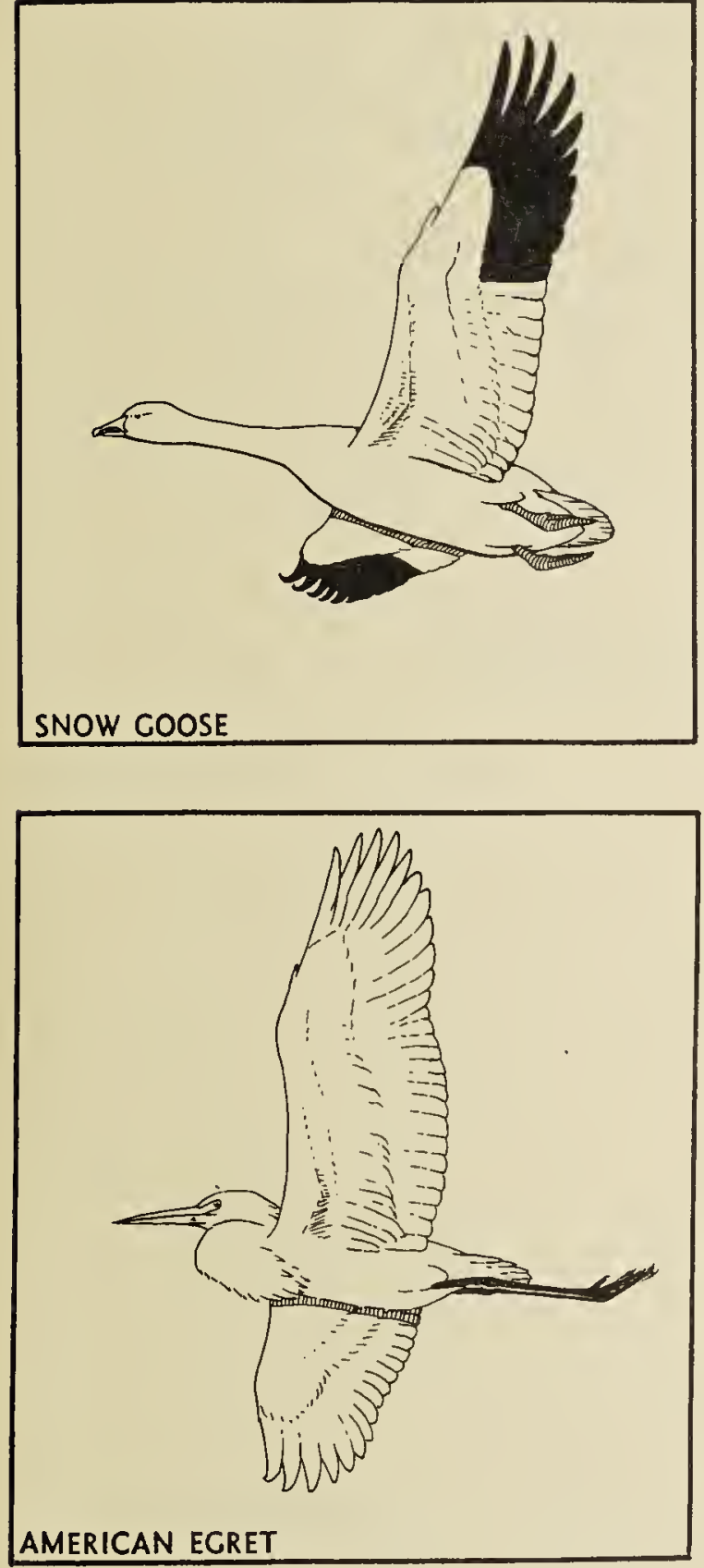

AMERICAN ECRET
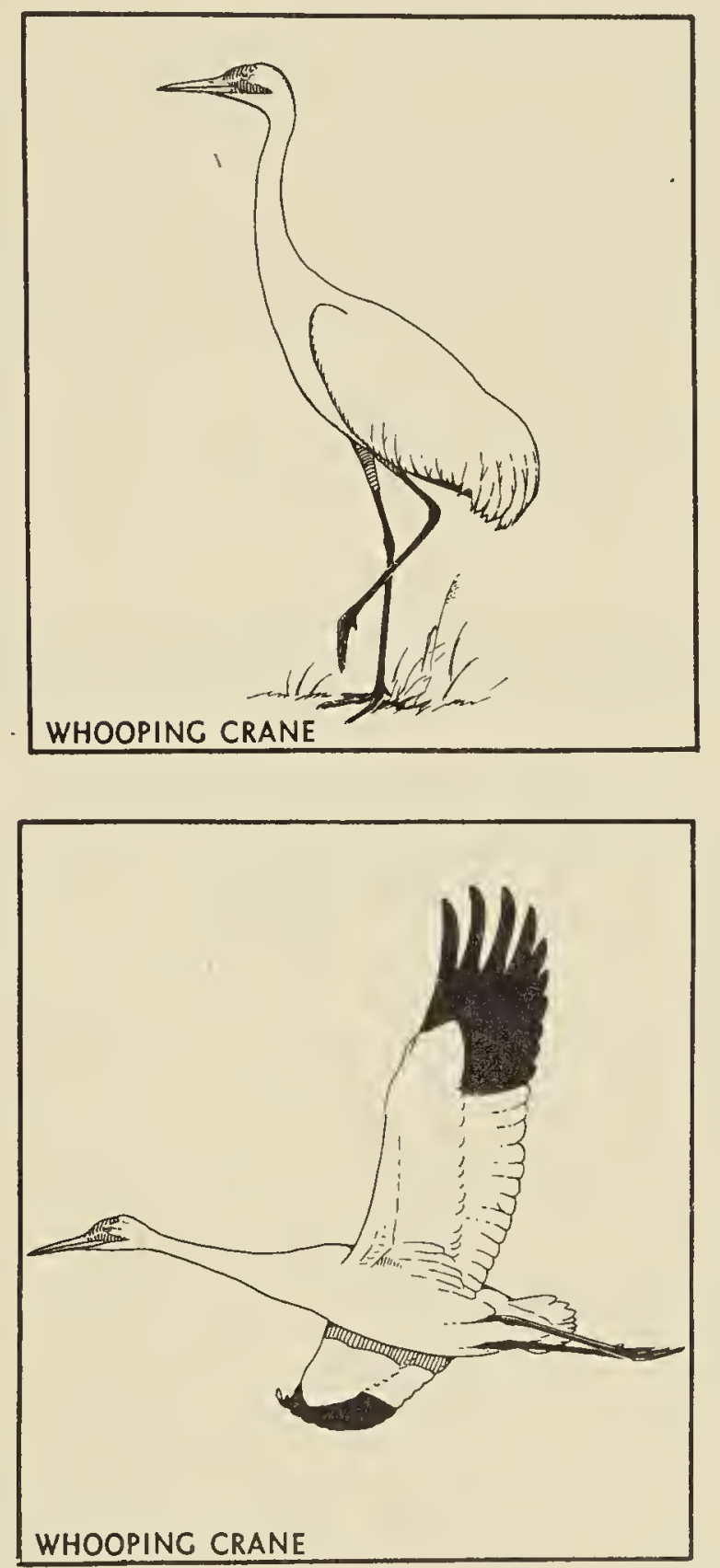

Note the pictures of the Whooping Crane and of other white birds with which it may be confused.

THE WHOOPING CRANE:

Stands over 4 feet tall.

Has a wing-spread of 7 feet.

flies with neck and legs out straight.

Has a white plumage except for black tips on wings.

Has black legs and yellow bill.

Has a bare red crown.

Usually nests in big marshes.

Illustrations by W. J. Breckenridge
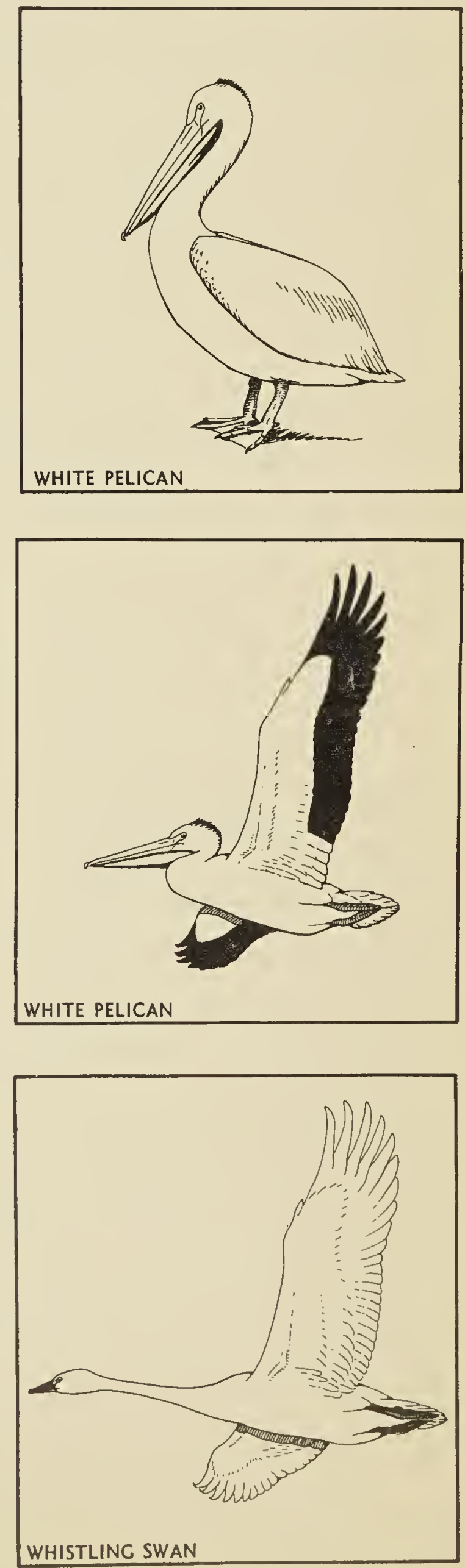


\section{HAVE YOU SEEN A WHOOPING CRANE?}

Somewhere in the marsh areas north of the prairies, a few birds are still living. Help us to save these beautiful creatures from extinction.

The National Audubon Society of New York and the Fish and Wildlife Service of Washington are working together to locate and protect the last of these noble birds.

Acting on their behalf we ask everyone to assist us to locate the nesting sites of the Whooping Crane. Life history studies are to be made, protection given, and motion pictures produced for educational purposes.

The work you are engaged in may be well suited to assist us in our efforts. If we are successful in saving this beautiful bird it will be a lasting tribute to all.

Please report any occurrences on the attached form, and cut on the dotted line.

\section{WHOOPING CRANE INVESTIGATION, 1946}

Fred G. Bard, Curator,

Prov. Museum, Normal School,

Regina, Sask.

Name

P.O.

Dates Seen

Years

Number Seen

Nearest known locality or map location:

Birds were seen: Flying.

Feeding.

Marsh

Stubble

Prairie

Other Remarks: 